\title{
Determination of the Effect of Cutting Direction and Grit Sizes of the Abrasive on Surface Roughness of Scotch Pine (Pinus sylvestris L.) and Oriental Beech (Fagus orientalis L.) Woods
}

\author{
Selçuk DEMİRCİ
}

Ege University, Ege Higher Vocational School, Furniture and Decoration, 35100, İzmir, TURKEY selcuk.demirci@ege.edu.tr

Received Date: 01.10.2018

Accepted Date: 12.04 .2019

Abstract

Aim of the study: In this study; effects of the grit size of abrasive and cutting direction on surface quality of sanded Scotch pine and Oriental beech woods were investigated.

Material and Methods; Scotch pine and Oriental beech which are commonly used in furniture sector were chosen. Specimens were sanded with three different grit sizes of abrasives; namely, 40, 60, and 80grit. The surface roughness of specimens was measured using Mitutoyo Surfest SJ-301 stylus scanner device on the basis of TS 2495 EN 3274 and TS 6956 EN ISO 4287. In total, 36 test samples were used for the experiments and each specimen was divided into eight equal parts and two measurements were made perpendicular to grain at $20 \mathrm{~mm}$ length.

Main results: The smoothest surface was obtained from the Scotch pine when sanded at tangential section with 80 -grit abrasives. The roughest surface was obtained from the Oriental beech when sanded at tangential section with 40-grit abrasives.

Highlights: Especially, in the production of wooden furniture; after the wood materials are cut with circular saws, smooth surfaces can be obtained by sanding them with a 60 and 80-grit abrasives without planing. This will provide economic benefits to producers.

Keywords: Scotch pine, Oriental beech, Sanding, Abrasive, Cutting direction, Surface Roughness

\section{Kesiş Yönü ve Zımpara Tanecik Sayısının Sarıçam (Pinus sylvestris L.) ve Doğu Kayını (Fagus orientalis L.) Odunlarının Yüzey Pürüzlülüğüne Etkilerinin Belirlenmesi}

Öz

Çalışmanın amacı: Bu çalışmada; zımparalanmış sarıçam ve doğu kayını odunlarında, kesiş yönü ve zımpara çeşidinin yüzey kalitesine etkileri araştırılmıştır.

Materyal ve Yöntem: Denemeler için mobilya sanayisinde en çok kullanılan sarıçam ve Doğu kayını odunları seçilmiştir. Örnekler 40, 60 ve 80 kum, 3 farklı zımpara ile zımparalanmıştır. İşlenen numunelerin yüzey düzgünlük ölçümleri TS 2495 EN 3274 ve TS 6956 EN ISO 4287 esaslarına göre yapılmıştır. Yüzey düzgünlük ölçümlerinin değerlendirilmesinde, iğne taramalı ölçme yapan Mitutoyo Surfest SJ-301 cihazı kullanılmıştır. Denemeler için 36 adet test numunesi kullanılmış ve her örnek 8 eşit parçaya bölünerek bu bölümlerden liflere dik yönde ve $20 \mathrm{~mm}$ boyunda iki ölçme yapılmıştır.

Sonuçlar: Deney sonuçlarına göre en düzgün yüzey; sarıçam odununda, teğet yüzeyde, 80 numaralı zımpara ile elde edilmiştir. En pürüzlü yüzey ise; doğu kayını odununda, teğet yüzeyde, 40 numaralı zımpara ile elde edilmiştir.

Araştırma Vurguları: Özellikle ahşap mobilya imalatında; ağaç malzemeler daire testerelerle biçildikten sonra, rendeleme işlemi yapılmadan 60 ve 80 kum zımparalarla zımparalanarak düzgün yüzeyler elde edilebilir. Bu durum üreticilere ekonomik fayda sağlayacaktır.

Anahtar kelimeler: Sarıçam, Doğu kayını, Zımparalama, Zımpara, Kesiş yönü, Yüzey Pürüzlülüğü

\section{Introduction}

The furniture is divided into two groups as interior and outdoor furniture. Interior furniture are living room, dining room, bedroom furniture etc. The surface quality of wood materials used in interior furniture is expected to be very high. Outdoor furniture is generally known as garden furniture. However, the pergola, doors and windows manufactured in the outdoor areas are also 
included in this category. In their manufacturing, wood materials are used extensively. These furniture made of wood materials are used extensively in summer houses and hotels. Pine wood is used in outdoor furniture and beech wood is used occasionally in indoor furniture. The surface quality of the wood materials to be used in outdoor furniture is considered to increase the cost and therefore the surface quality is not taken into account. In this type of production, the wood materials are shipped without proper planing and sanding. However, sanding is very important for furniture made of wooden material. By sanding the machine traces are removed and a smoother surface is obtained for the paind treatment.

Richter et al. investigated the factors affecting surface roughness in different woods. At the end of the study, they determined that number of cutter, cutting depth, cutting direction, feed rate and sanding were effective. (Richter, Feist \& Knaebe, 1995).

It is found that surface smoothness can be increased by increasing the number of cutter and grain while grating and sanding process in different tree species (Ors and Baykan, 1999, Ors and Gurleyen, 2002, Usta, Demirci and Kilıc, 2007). In addition to this, since the wood material is heterogeneous, it shows dissimilar endurance properties in accordance with the direction of intersection. It affects the resistance properties of moisture and extra substances in the tree. This affects the processing performance of the material on the machines. Gurleyen, Yalcınkaya and Baykan have determined that more smooth surfaces are obtained in the sanding and grating operations performed in tangential direction (Baykan, 1995, Yalcınkaya, 1997, Gurleyen, 1998).

Kılıc, Hiziroğlu and Burdurlu (2006) have determined that there is no significant difference in the $95 \%$ confidence interval for the measurements of surface roughness in radial and tangential directions. They stated that the difference between surface roughness of beech and poplar wood was statistically significant. As a result of the study, it has been found that stylus method is successful in surface roughness measurement in grating and sanding processes.

Sogutlu suggests that the highest value for surface roughness value was found on the oak examples while the lowest value was obtained on the pear samples. Furthermore, according to radial and tangential direction, the sanding paper of 80 numbered has given the roughest surface in comparisons with using the sanding paper of 120 numbered (Sogutlu, 2005).

In Gurau, Williams and Irle (2005) stated that there are irregularities in wood materials due to both sanding and anatomical structure. Therefore, it is stated that surface roughnesses of wood materials should be taken out from the measurement while measuring the roughnesses caused by anatomical reasons. They found that the standard filters used in measuring surface roughness of oak, beech and spruce wood sanded with 1000-grit abrasives gave incorrect results and Gauss filters gave errorfree results.

De Moura and Hernandez (2006) sanded the test specimens with two different abrasives, three different particle sizes and different feed rates. When they evaluated the surface quality, they found that the treatments with 150-grit sanders gave smoother surfaces compared to the processes with 100-grit sanders. It has been determined that the damage in the cells of the materials is reduced in the operations made with 150grit abrasives. They also found that as the feed rate increases, the roughness increases in the sanding of the samples.

Ratnasingam and Scholz (2006) have found that smoother surfaces are achieved with the number 240 sanders, and that the surface of the materials treated with number 240 sanders are brighter. They also stated that companies should standardize surface roughness in production in order to improve the surface quality of wood materials.

Aslan, Coskun and Kilıc (2008) determined that the cutting direction of wood material affects the surface smoothness. They found that in Taurus cedar wood, more smooth surfaces were obtained in radial cuts, while rough surfaces were obtained in tangential cuts. They stated that surface quality increases with increasing sand 
number of abrasives used in sanding operations, surface quality decreases as sand number decreases.

Suleyman, Hasim, Subari and Liang (2009) stated that sanding process on wood materials increases the quality of the material surface. They found that as the size of the particles increased, the rough surfaces and the smaller the number of particles, the smoother surfaces were obtained. They found that the rubber tree had smoother surfaces in the tangential direction than the radial direction.

Sogutlu determined that the surface roughness decreases as the cutting speed increases in the grating of wood materials. In the evaluation made according to the direction of exploration of the materials, it was found that the surfaces were obtained more smoothly in the tangential direction than the radial direction. In addition, it has determined that surface roughness decreases as feed rate decreases and surface roughness increases as feed rate increases (Sogutlu, 2010).

Tan, Sharif and Sudin (2012), in their study sanding particle size and feeding speed were determined to be statistically significant. They also stated that three random measurements of surface roughness may be sufficient.

The surface of the wood types which were planed with a higher number of knives is better when compared to those planed with less number of knives. It means that as the number of knives increases, the amount of waviness in the surface decreases. Furthermore, the average surface quality values of the wood types evaluated in this research could be estimated by means of the developed equations (Demirci, 2013).

Kilıc (2015), in his study, made grating, mowing and sanding operations in black pine wood and determined that grating gives smoother surfaces compared to mowing and sanding (80-grit) processes. It also found that more smooth surfaces were obtained in the tangential direction than the radial direction.

K1lic (2017) investigated the surface roughness of Turkish red pine woods obtained from different provinces. Considering the results of the study, the smoothest surfaces were obtained in the woods obtained from Samsun and Mugla. In addition, according to the machine in which the wood material is processed, the smoothest surface thickness machine was obtained in the grating made in tangential direction on the machine.

Kilıc, Purlusoy and Kurnalı (2018) found that the lowest roughness values were achieved with the thickness machine. Similarly, the roughness values of tangentially cut surfaces were found to be lower than the radially cut surfaces.

Surface quality is very important in furniture manufacturing. It is known that the cutting direction, cutters and sanding affect the surface quality. Sanding is the latest process for smoothness. However, it was observed that the number of abrasive grains used in the furniture industry during manufacturing was not considered.

The aim of this study is to determine the effect of the cutting direction and the type of sanding on the surface smoothness of the wood used in the production of wood furniture. In this study surface roughness of Scotch pine and Oriental beech wood that are commonly utilized in furniture sector were investigated as they are sanded by the abrasives (40, 60 and 80 grit size) with different cutting direction (tangential and radial).

\section{Materials and Method}

\section{Woods and Abrasive}

In this study, Scotch pine (Pinus sylvestris L.) and Oriental beech (Fagus orientalis L.), which are the most commonly used wood types in furniture manufacturing, were used as wood materials.

As the type of sandpaper, the most preferred sanding machines with 3 different grain numbers were used in the sanding machines in furniture enterprises. Grit size of the abrasive and usage areas are given in Table 1. 
Table 1. Grit sizes of the abrasive and usage areas (Afyonlu, 1995)

\begin{tabular}{ccl}
\hline Category of abrasives & Grit sizes of the abrasive & \multicolumn{1}{c}{ Usage areas } \\
\hline Extra thin & $320-600$ & Correction of last paint finish \\
\hline Very thin & $220-280$ & Abrasive flooring \\
\hline Thin & $120-180$ & The last sanding operation before varnishing \\
\hline Medium & $60-80$ & Sanding of fine pour finishes \\
\hline Thick & $40-50$ & Sanding of rough finishes \\
\hline Very thick & $24-36$ & Sanding of very rough finishes \\
\hline Extra thick & $12-20$ & Extra rough sanding finishes \\
\hline
\end{tabular}

\section{Description of specimens}

Test specimens were kept at $20 \pm 2^{\circ} \mathrm{C}$ and $65 \pm 3 \%$ relative humidity before cutting. Thus, the samples were dried to constant weight. The determination process of moisture contents (MC) and densities of the woods were performed in accordance with TS 2470 and TS 2471, respectively (TS 2470 and TS 2471, 1976). Thus, the average moisture content of the wood samples to be tested was increased to $12 \%$. Then, wood materials with $12 \%$ moisture were cut in tangential and radial directions.

Surface roughness test specimen sizes were $100 \times 100 \times 10 \mathrm{~mm}$. All specimens were sanded at the direction of parallel to grain and in the sanding process, sanding block were utilized in order to obtain a properly and homogeneous sanded surfaces.

\section{Plan of the Study}

Altogether, 12 sets of specimens consisting of 3 replications for each, 2 wood types (Scotch pine and Oriental beech), 2 cutting direction (tangential and radial surface) and 3 grit sizes of abrasives (40, 60 and 80 ), or a total of 36 specimens were prepared for surface roughness tests. In total, All samples were measured perpendicular to the fibers. 8 different points were measured in each sample. A total of 288 measurements were made in all experimental samples. Then, statistical analysis of these measured values was performed.

\section{Testing}

The Mitutoyo Sj-301 tester used for measuring the surface smoothness in the test samples is given in figure 1 . The measurement of the test samples was carried out within the scope of the recommendations of the manufacturer of the test device. The measurement; range: $12.5 \mathrm{~mm}$, speed: 0.25 $\mathrm{mm} / \mathrm{s}$, tip diameter: $90^{\circ} / 5 \mu \mathrm{mR}$, shear force: less than $400 \mathrm{mN}$. In order to prevent deformation on the surfaces of the samples during the measurements, measurements were made in a noiseless and vibration free environment. The temperature of the environment where the measurements were made was determined as $20 \pm 2^{\circ} \mathrm{C}$ relative humidity and $65 \pm 3 \%$.
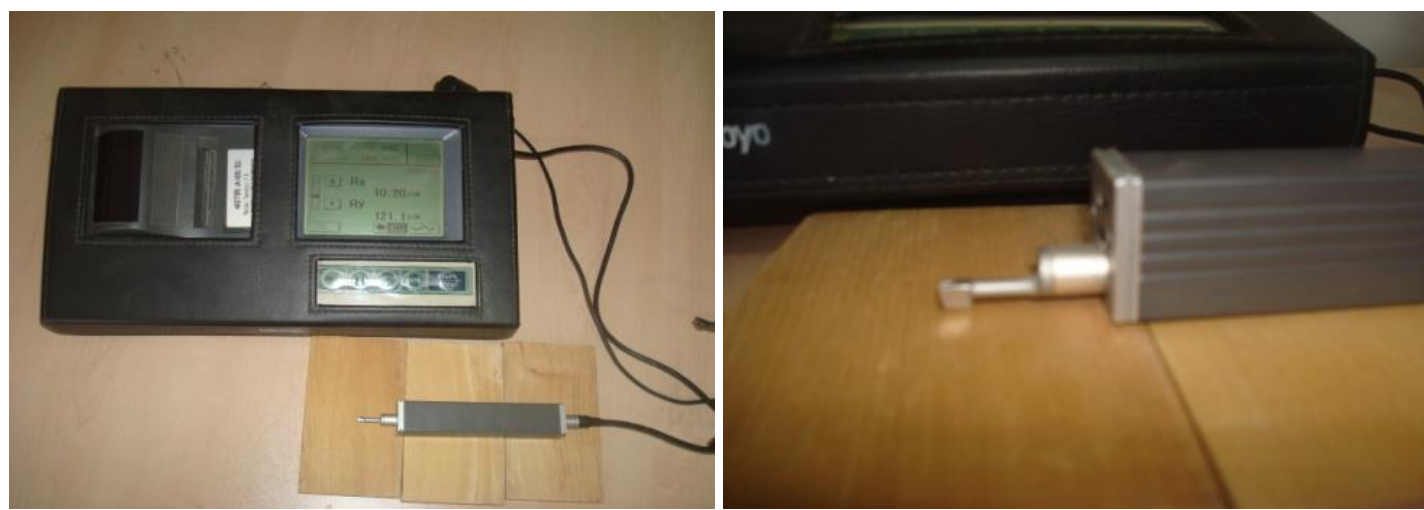

Figure 1. Mitutoyo Sj-301 tester used in test samples 
In the measurements, surface smoothness was evaluated and the ratio was determined as 0.01. During the measurement, scanning length (lt) was set to be $12.5 \mathrm{~mm}$ and sample length to be $2.5 \mathrm{~mm}$. (Anonym). The measurements were also performed in accordance with the procedures of TS 6956 EN ISO 4287 and TS 2495 EN 3274 (TS 6956 EN ISO 4287 and TS 2495 EN 3274, 2004, 2005).

\section{Results and Discussion}

Oven dry and air dry densities of the specimens tested are given in Table 2. Mean surface roughness values of the specimens that were determined according to wood types, cutting direction and grit size of abrasive on surface roughness are given in Table 3 .

Table 2. Densities of the wood types used tested in this study (TS 2472, 1976)

\begin{tabular}{lcc}
\hline Wood types & Oven dry density $\left(\mathrm{gr} / \mathrm{cm}^{3}\right)$ & Air dry density $\left(\mathrm{gr} / \mathrm{cm}^{3}\right)$ \\
\hline Scotch pine & 0.50 & 0.53 \\
\hline Oriental beech & 0.64 & 0.66
\end{tabular}

A total of 288 measurements were performed on 36 test samples. The analysis of variance (ANOVA) was performed for the results obtained from the measurements. In variance analysis, the effect of wood type, cutting direction and number of abrasive abrasive particles on surface roughness was determined statistically. In addition, the interactions of wood type, cutting direction and number of abrasive particles were investigated. The results of the variance analysis are presented in Table 4. In accordance with the results of the analysis, effects of the main factors including wood types $(A)$, cutting direction $(B)$ and sanding type $(C)$ are found to be statistically significant at the level of 0.05 . Furthermore, three factor interactions of wood types $(A) \times$ cutting direction $(B) \times$ sanding type $(C)$ were also statistically significant $(\mathrm{p}<0.05)$. However, two factor interactions of wood types $\times$ cutting direction $(A \times B)$, wood types $\times$ sanding type $(A \times C)$, cutting direction $\times$ sanding type $(B \times C)$ were not statistically significant.

Table 3. Mean values of surface smoothness (Ra) $\mu \mathrm{m}$

\begin{tabular}{cccccccccccccccc}
\hline Wood types & \multicolumn{4}{c}{ Scotch pine } & \multicolumn{8}{c}{ Oriental beech } \\
\hline $\begin{array}{c}\text { Cutting } \\
\text { direction }\end{array}$ & $\begin{array}{c}\text { Tangential } \\
\text { surface }\end{array}$ & \multicolumn{2}{c}{$\begin{array}{c}\text { Radial } \\
\text { surface }\end{array}$} & \multicolumn{2}{c}{$\begin{array}{c}\text { Tangential } \\
\text { surface }\end{array}$} & \multicolumn{4}{c}{$\begin{array}{c}\text { Radial } \\
\text { surface }\end{array}$} \\
\hline $\begin{array}{c}\text { Grit size of } \\
\text { abrasive }\end{array}$ & 40 & 60 & 80 & 40 & 60 & 80 & 40 & 60 & 80 & 40 & 60 & 80 \\
\hline $\begin{array}{c}\text { Maximum } \\
\text { Value }\end{array}$ & 9.75 & 7.23 & 5.60 & 8.52 & 7.22 & 6.10 & 9.62 & 8.44 & 6.50 & 9.53 & 8.71 & 5.23 \\
\hline $\begin{array}{c}\text { Minimum } \\
\text { Value }\end{array}$ & 13.0 & 10.3 & 8.39 & 12.4 & 9.49 & 7.86 & 13.5 & 9.95 & 10.2 & 12.6 & 10.0 & 8.80 \\
\hline Mean (X) & 10.9 & 8.6 & 6.61 & 10.5 & 8.5 & 6.8 & 11.3 & 8.9 & 7.9 & 10.9 & 9.3 & 7.13 \\
\hline $\begin{array}{c}\text { Standard } \\
\text { Davition (s) }\end{array}$ & 0.90 & 0.97 & 0.76 & 1.17 & 0.69 & 0.56 & 1.15 & 0.53 & 0.89 & 0.97 & 0.44 & 0.97 \\
\hline
\end{tabular}


Table 4.The results of ANOVA

\begin{tabular}{lccccc}
\hline Source & $\begin{array}{c}\text { Degrees of } \\
\text { Freedom }\end{array}$ & $\begin{array}{c}\text { Sum of } \\
\text { Squares }\end{array}$ & Mean Square & $\begin{array}{c}\text { Value } \\
\mathrm{F}\end{array}$ & $\mathrm{P}<0.05$ \\
\hline Wood types (A) & 1 & 29.741 & 29.741 & 39.1529 & 0.0000 \\
\hline Cutting direction (B) & 1 & 3.182 & 3.182 & 4.1883 & 0.0417 \\
\hline AxB & 1 & 0.401 & 0.401 & 0.5282 & $\mathrm{~ns}$ \\
\hline Grit size of abrasive (C) & 2 & 669.404 & 334.702 & 440.6180 & 0.0000 \\
\hline AxC & 2 & 2.369 & 1.185 & 1.5595 & $\mathrm{~ns}$ \\
\hline BxC & 2 & 4.315 & 2.158 & 2.8403 & $\mathrm{~ns}$ \\
\hline AxBxC & 2 & 7.960 & 3.980 & 5.2396 & 0.0058 \\
\hline Error & 276 & 209.655 & 0.760 & - & - \\
\hline Total & 287 & 927.028 & - & - & - \\
\hline
\end{tabular}

ns: non-significant

The least significant difference (LSD) multiple comparisons procedure at a $5 \%$ significance level was performed to determine the mean differences considering the cutting direction, grit size of abrasive, wood types, and their twoway and three-way interactions that were statistically significant in the ANOVA results. Thus, homogeneous groups are determined.

Comparison results in accordance with the wood types are shown in Figure 2. When Scotch pine and Oriental beech were sanded, the smoothest surface was obtained in the Scotch pine. This may be not only the anatomical features but also the density of Scotch pine wood which is less than the Oriental beech wood. The wood does not have o homogeneous structure. Each wood has different characteristics with respect to structure. In the light of this information, the result obtained in terms of the wood types used in the experiments are consistent with the studies in the literature.

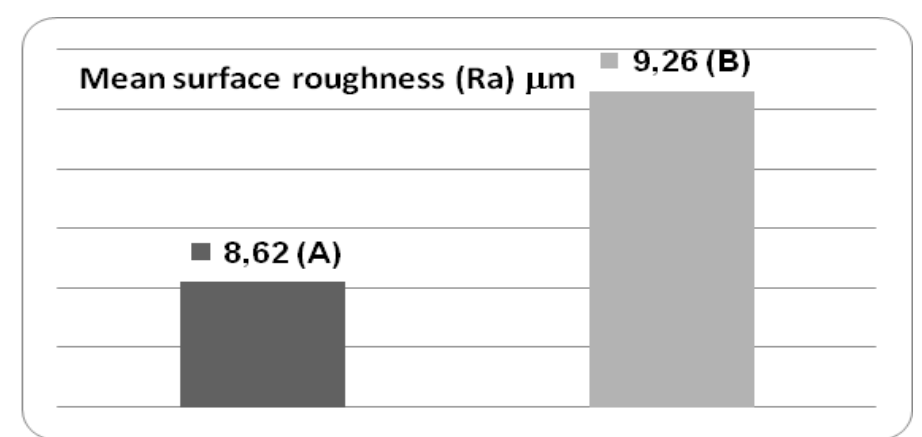

Figure 2. Comparison results according to wood types $(L S D \pm 0.2022)$

In accordance with the interaction of the cutting direction, the comparison results are given in Figure 3. In accordance with the cutting direction, smoother surface is obtained in the tangential surface. This may be due to the texture differences in tangential and radial surfaces. In the comparison with the studies conducted in the literature in terms of cutting direction, the results of the study are shown in Ors \& Baykan (1999), Ors \& Gurleyen (2002), Usta et al. (2007), Sogutlu (2010) and Sulaiman et al. (2009). It was found to be compatible with studies. 


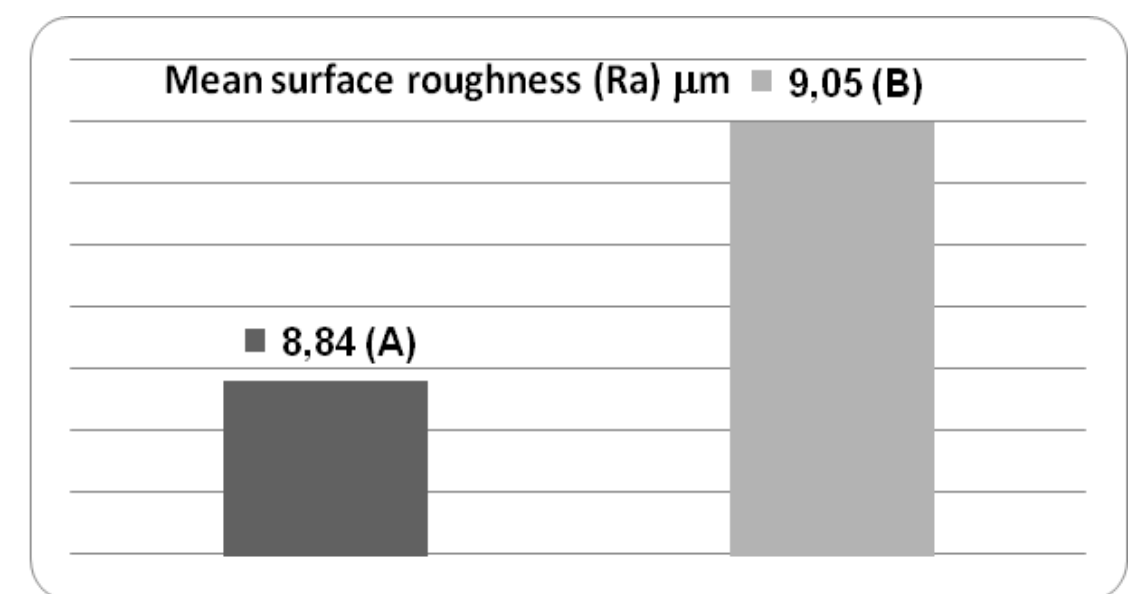

Figure 3. Comparison results according to cutting direction $(L S D \pm 0.2022)$

In accordance with the interaction of the grit sizes of the abrasive, the comparison results are shown in Figure 4. When the grit sizes of the abrasive material is considered, the success order is 80-grit, 60-grit and 40grit number abrasives, as expected. As the particle size of the abrasives used in sanding increases, the particle sizes are reduced, resulting in smoother surfaces. When the studies in the literature are examined, it is determined that the increase in the number of abrasive particles used in the abrasives increased the surface smoothness of the woods.

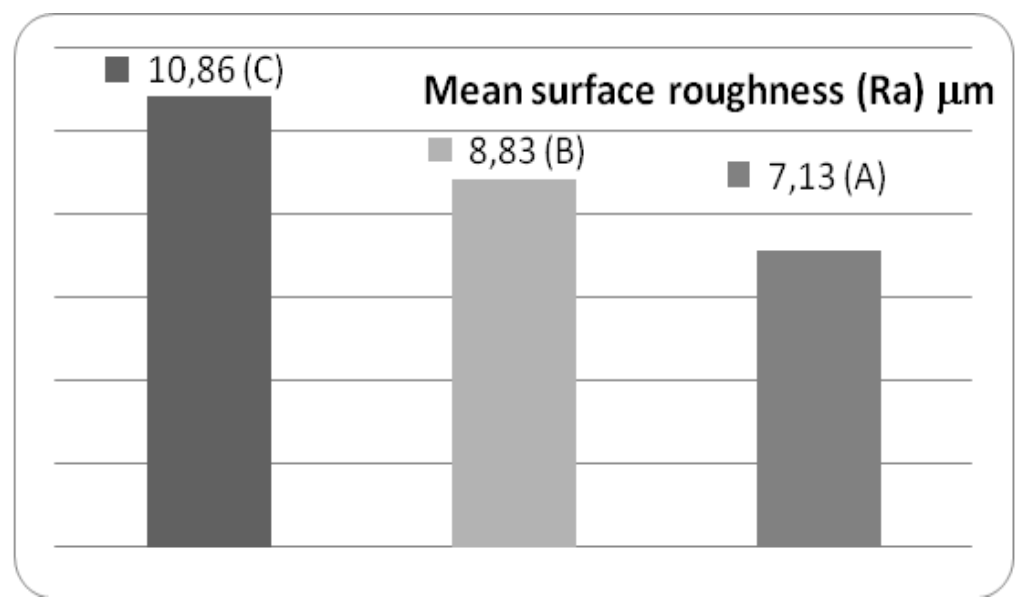

Figure 4. Comparison results according to grit sizes of abrasive $(L S D \pm 0.2477)$

When the wood types $\times$ cutting direction $\times$ grit sizes of abrasive three-way interaction are considered; the quality surfaces were obtained with the Scotch pine $\times$ tangential surface $\times 80$-grit abrasive, Scotch pine $\times$ radial surface $\times 80$-grit abrasive and Oriental beech $\times$ radial surface $\times 80$-grit abrasive combinations. The roughest surfaces were obtained with the Oriental beech $\times$ tangential surface $\times 40$-grit abrasive, Scotch pine $\times$ tangential surface $\times 40$-grit abrasive and Oriental beech $\times$ radial surface $\times 40$-grit abrasives. When wood types and intersection are taken into consideration, it is observed that the surface smoothness decreases as the number of cutters increases according to the literature. LSD comparison analysis results are given in Table 5 in accordance with wood types $\times$ cutting direction $\times$ grit sizes of abrasive three-way interaction. 
Table 5. Mean value of surface roughness according to wood types $\times$ cutting direction $\times$ grit sizes of abrasive

\begin{tabular}{lcc}
\hline $\begin{array}{l}\text { Wood types x Cutting direction } \\
\text { abrasive }\end{array}$ & Grit sizes of & Mean surface roughness (Ra) $\mu \mathrm{m}$ \\
\cline { 2 - 3 } & $\bar{X}$ & $H G$ \\
\hline Scotch pine - Tangential surface - 40 grit & 10.86 & $\mathrm{FG}$ \\
\hline Scotch pine - Tangential surface - 60 grit & 8.58 & $\mathrm{CD}$ \\
\hline Scotch pine - Tangential surface - 80 grit & 6.62 & $\mathrm{~A}$ \\
\hline Scotch pine - Radial surface - 60 grit & 10.44 & $\mathrm{~F}$ \\
\hline Scotch pine - Radial surface - 60 grit & 8.43 & $\mathrm{BC}$ \\
\hline Scotch pine - Radial surface - 60 grit & 6.79 & $\mathrm{~A}$ \\
\hline Oriental beech - Tangential surface - 40 grit & 11.27 & $\mathrm{G}$ \\
\hline Oriental beech - Tangential surface - 60 grit & 8.95 & $\mathrm{DE}$ \\
\hline Oriental beech - Tangential surface - 80 grit & 7.99 & $\mathrm{~B}$ \\
\hline Oriental beech - Radial surface - 40 grit & 10.86 & $\mathrm{FG}$ \\
\hline Oriental beech - Radial surface - 60 grit & 9.38 & $\mathrm{E}$ \\
\hline Oriental beech - Radial surface - 80 grit & 7.13 & $\mathrm{~A}$ \\
\hline
\end{tabular}

$L S D \pm 0.4953$

\section{Conclusions}

Purpose of this study was to determine the effect of cutting direction and the grit sizes of abrasive on the surface smoothness of wood used in the production of wooden furniture. In the scope of the study, surface roughness of Scotch pine and Oriental beech woods that are mostly exploited in furniture industry were researched as they are sanded with the different grit sizes of the abrasives $(40,60$ and 80-grits) on different cutting direction (tangential and radial surfaces).

As a result, the surface quality of Scotch pine and Oriental beech woods can be upgraded by processing with the 80 -grit abrasive which has a high grain count.

However, as the number of operations increases with 80-grit abrasive, the sanding pores will quickly fill up, an this will cause friction and burning on the abrasive and this will reduce the efficiency. If this is taken into account, in the case of work to be done except from very special purposes for the sake of economic contribution to the manufacturer, using 60-grit abrasive can improve both the life of the abrasive and the working efficiency.

Especially in the production of wood furniture; after the wood materials are cut with circular saws, smooth surfaces can be obtained by sanding them with a 60 and 80 - grit size sandblasters without planing. Thus, the finishing process time can be shortened.

\section{Acknowledgements}

I would like to thank to all staff in Department of Woodworking Industrial Engineering, Mugla Sitk1 Kocman University for contributing to the success of this study. Preliminary data of this study were verbally presented at the $4^{\text {th }}$ National Vocational Schools Symposium which held in İzmir, Turkey, 2007 (Demirci, 2007). Then, data sets were expanded before converting into a scientific manuscript.

\section{References}

Afyonlu, S.A. (1995). Woodwork tools and machine knowledge. İstanbul: Ministry of Education.

Anonym, Mitutoyo SJ-301 Using Guide, Minato$\mathrm{Ku}$, Tokyo, Japan.

Aslan, S., Coskun H. \& Kilıc, M. (2008). The effect of the cutting direction, number of blades and grain size of the abrasives on surface roughness of Taurus cedar (Cedrus Libani A. Rich.) wood. Building and Environment, 43(5), 696-701.

Baykan, I. (1995). The research the surface roughness of the planed and sanded solid furniture. PhD. thesis, Institute of Science and Technology, Karadeniz Tecnical University, Trabzon, pp.98.

De Moura, L. F. \& Hernández, R. E. (2006). Effects of abrasive mineral, grit size and feed 
speed on the quality of sanded surfaces of sugar maple wood. Wood Science and Technology, 40(6), 517-530.

Demirci, S. (2007). A research on the roughness values of sanded Scotch pine and Oriental beech materials. $4^{\text {th }}$ National Vocational Schools Symposium in İzmir, Turkey, 503507.

Demirci, S. (2013). Effect of the number of knives, feed rate, and cutting depth on surface roughness of some wood types processed with planer. Kastamonu University Journal of Forestry Faculty, 13(1), 100-108.

Gurau, L., Mansfield-Williams, H. \& Irle, M. (2005). Processing roughness of sanded wood surfaces. Holz als Roh-und Werkstoff, 63(1), 43-52.

Gurleyen, L. (1998). Comparison of surface smoothness in the materials of solid wood using in the furniture. MSc. thesis, Institute of Science and Technology, Gazi Univ, Ankara, $62 \mathrm{pp}$.

Kılıc, M., Hiziroğlu, S, \& Burdurlu, E. (2006). Effect of machining on surface roughness of wood. Building and Environment, 41(8), 1074-1078.

Kilıc, M. (2015). Effect of machining methods on the surface roughness values of Pinus nigra Arnold wood. BioResources, 10(3), 55545562.

Kilic, M. (2017). Determination of the surface roughness values of Turkish Red pine (Pinus brutia (Ten.)) woods. BioResources, 12(1), 1216-1227.

Kilıc, M., Purlusoy I. \& Kurnalı M. (2018). Measuring the surface roughness values of European hop-horn beam (Ostrya carpinifolia Scop.). Wood Research, 63(2), 343-352.

Ors, Y. \& Baykan, I. (1999). The effect of planing and sanding surface roughness of massive wood. Turkish Journal of Agriculture and Forestry, (23), 577-582.

Ors, Y. \& Gurleyen, L. (2002). Effect of the cutting direction, number of knives and cutter species to surface smoothness on wood material for planning. Journal of Polytechnic of Gazi University, 5(4), 335-339.

Ratnasingam, J. \& Scholz, F. (2006). Optimal surface roughness for high-quality finish on rubberwood (Hevea brasiliensis). Holz als Roh-und Werkstoff., 64(4), 343-345.

Richter, K.W., Feist, W.C. \& Knaebe, M.T. (1995). The effect of surface roughness on the performance of finishes. Forest Products Journal, 7-8(45), 91-97.

Sogutlu, C. (2005). The effect of some factors on surface roughness of sanded wood material. Journal of Polytechnic of Gazi University, 8(4), 345-350.

Sogutlu, C. (2010). The effect of the feeding direction and feeding speed of planing on the surface roughness of oriental beech and Scotch pine woods. Wood Research, 55(4), 67-78.

Sulaiman, O., Hashim, R., Subari, K. \& Liang, C.K. (2009). Effect of sanding on surface roughness of rubberwood. Journal of Materials Processing Technology, 209, 39493955.

Tan, P. L., Sharif, S. \& Sudin, I. (2012). Roughness models for sanded wood surfaces. Wood Science and Technology, 46(1-3), 129-142.

TS 2495 EN ISO 3274 (2005). Geometrical product specifications (GPS)-surface texture: profile method-nominal characteristics of contact (stylus) instruments. Ankara: Turkish Institute of Standards.

TS 2470 (1976). Wood-sampling methods and general requirements for physical and mechanical tests. Ankara: Turkish Institute of Standards.

TS 2471 (1976). Wood-determination of moisture content for physical and mechanical tests. Ankara: Turkish Institute of Standards.

TS 2472 (1976). Wood-determination of density for physical and mechanical tests. Ankara: Turkish Institute of Standards.

TS 6956 EN ISO 4287 (2004). Geometrical product specifications (GPS)-surface texture: profile method-terms, definitions and surface texture parameters. Ankara: Turkish Institute of Standards.

Usta, I. Demirci, S. \& Kilıc, Y. (2007). Comparison of surface rouphness of locust acacia (Robinia pseudoacacia L.) and european oak (Quercus petraea lieble) in terms of the preparative process by planning. Building and Environment, 42(8), 2988-2992.

Yalcınkaya, O. (1997). Studies on surface roughness values of european oak (quercus petraea lieble) and crimean pine (pinus nigra arn.), MSc. thesis, Institute of Science and Technology, Hacettepe University, Ankara, $74 \mathrm{p}$ 